Proc. Estonian Acad. Sci. Biol. Ecol., 2003, 52, 1, 17-25

\title{
Chronology of embryonic development in Baltic herring Clupea harengus membras
}

\author{
Aune Veersalu and Toomas Saat \\ Estonian Marine Institute, University of Tartu, Mäealuse 10a, 12618 Tallinn, Estonia \\ Received 27 February 2002, in revised form 22 October 2002

\begin{abstract}
Thirty stages were distinguished in the development of the Baltic herring embryo during the period from insemination to hatching. The age of embryos at these stages was expressed in relative time units $\left(\tau_{0}\right)$ and the timing of herring embryo development was compared with data for other teleosts. The chronology of Baltic herring's embryonic development was rather similar to that of salmonid fishes and differed from that of cyprinid fishes.
\end{abstract}

Key words: Clupea harengus membras, development chronology, temperature, heterochrony.

\section{INTRODUCTION}

Chronology and heterochronies of early development may have ecological and evolutionary importance (Emelianov, 1968; Balon, 1981, 1983; Paine \& Balon, 1984; Fuiman, 1985). Correct comparisons of developmental chronology in poikilotherms, including fish, cannot be made on the basis of data expressed in astronomic time units (hours, minutes, etc.), or in "degree-hours" or "degreedays", as the species-specific development rate also depends on environmental factors (primarily on temperature), and this dependence is not linear (Dettlaff et al., 1987; Saat \& Veersalu, 1996a).

The duration of one mitotic cycle during the period of synchronous cleavage divisions $\left(\tau_{0}\right)$ has been proved to be a proper unit to compare the duration of developmental processes in different species and at different temperatures (Dettlaff \& Dettlaff, 1961; Dettlaff et al., 1987). The dependence of $\tau_{0}$ on temperature has been revealed for more than 10 teleost species, including Baltic

* Corresponding author, tsaat@sea.ee 
herring Clupea harengus membras L. (Saat \& Veersalu, 1996a). The timing (in numbers of $\tau_{0}$ ) of stages of normal development has been revealed for several species, including some freshwater and anadromous teleosts: rainbow trout Oncorhynchus mykiss (Walb.) (Ignatieva, 1991), Atlantic salmon Salmo salar (L.) (Gorodilov, 1983, 1990), carp Cyprinus carpio L. (T. Saat et al., unpublished), Carassius gibelio (Bloch) (Savolainen, 1985), and mud loach Misgurnus fossilis (L.) (Kostomarova, 1991). No such data are available for marine fish.

Kryzhanovskij (1956), Rannak (1961), and Ojaveer $(1981,1988)$ described the morphology of the embryonic development of some clupeid species, including Baltic herring. Ojaveer (1981) investigated the age of embryos of Baltic herring (expressed in degree-hours) at some stages and at three temperatures.

The aim of the present investigation was to compose a table of normal development for Baltic herring, reveal the timing of developmental stages (in numbers of $\tau_{0}$ ), and compare the temporal pattern of development in Baltic herring with that of representatives of Salmoniformes and Cypriniformes.

\section{MATERIAL AND METHODS}

Gametes of 12 females and 12 males (range of total length (TL) 15.2-19.7 cm) of spring spawning Baltic herring (12 crosses) were used in experiments carried out in the spawning period (April-June). Fish were obtained from commercial trap net catches from Pärnu Bay (Estonia). Eggs and sperm were stripped from live "running" specimens and fertilized in water from the bay (salinity $4 \mathrm{ppt}$ ) at $10^{\circ} \mathrm{C}$. The water was changed every 2 days. Eggs attached to pieces of the fishing net or to the bottom of Petri dishes were incubated in 10-15 litre tanks (500-700 embryos per tank) with continuous aeration at $4 \mathrm{ppt}$ salinity. The water temperature was $10.0^{\circ} \mathrm{C}$, which lies within the range of optimal temperatures for early development of this species (Saat \& Veersalu, 1996a). The temperature was measured every $2-4 \mathrm{~h}$. During the development of some batches of eggs some short-term fluctuations of temperature (between 9.5 and $12.3^{\circ} \mathrm{C}$ ) occurred. The age of embryos was expressed as multiples of $\tau_{0}\left(\tau_{n} / \tau_{0} ; \tau_{n}\right.$, time of appearance of a particular character in minutes from insemination). The values of $\tau_{0}$ at different temperatures $(t)$ between 1 and $13^{\circ} \mathrm{C}$ for Baltic herring embryos can be calculated as $\log \tau_{0}=2.4349-0.0684 t$ (Saat \& Veersalu, 1996a). At $10.0^{\circ} \mathrm{C}, \tau_{0}$ equals $56.3 \mathrm{~min}$. Approximately 30 embryos were sampled in every $0.25-2 \tau_{0}$ (more frequently until gastrulation) and investigated under a stereomicroscope. Stages of development were chosen according to those in tables of normal development of other teleost fish species (Gorodilov, 1983; Ignatieva, 1991; Kostomarova, 1991). Both living and preserved (in $4 \%$ formalin) embryos were examined and measured (TL in $0.1 \mathrm{~mm}$ ) using a dissecting stereomicroscope; drawings were made using drawing apparatus. E. Ojaveer prepared most of the drawings. The relative linear rate of epiboly (rate of moving cell blast boarder over yolk towards the vegetal pole of the egg) was measured according to Ignatieva (1979). 
As the timing of development varies markedly even within batches, the stages in the table of normal development are given for the most advanced embryos (cf. Dettlaff \& Vassetzky, 1991).

\section{RESULTS}

We distinguished 30 stages of normal development of the spring spawning Baltic herring embryo. A brief description of each stage as well as the ages of embryos are presented in Table 1. Most stages are illustrated in Fig. 1.

Table 1. Stages of Baltic herring development $\left(\log \tau_{0}=2.4349-0.0684 t\right.$ at $t=1-13^{\circ} \mathrm{C}$; Saat \& Veersalu, 1996a)

\begin{tabular}{|c|c|c|}
\hline Stage & $\begin{array}{l}\text { Age } \tau_{n} / \tau_{0} \\
(\text { mean } \pm \mathrm{SD} \\
\quad n=12)\end{array}$ & Description \\
\hline 0 & 0 & $\begin{array}{l}\text { Ovulated egg at the moment of insemination. Egg diameter } \\
0.8-1.09 \mathrm{~mm}\end{array}$ \\
\hline $0+$ & $0.6 \pm 0.5$ & Egg activation, narrow perivitelline space \\
\hline $1-$ & $2 \pm 0.5$ & $\begin{array}{l}\text { Activated egg. Egg diameter (incl. well developed perivitelline } \\
\text { space) } 1.1-1.4 \mathrm{~mm} \text {. Bipolar differentiation, formation of the } \\
\text { germinal disc }\end{array}$ \\
\hline 1 & $3 \pm 0.5$ & 2 blastomeres \\
\hline 2 & $4 \pm 0.5$ & 4 blastomeres \\
\hline 3 & $5 \pm 0.5$ & 8 blastomeres \\
\hline 4 & $6 \pm 0.5$ & 16 blastomeres \\
\hline 5 & $7 \pm 0.5$ & $\begin{array}{l}32 \text { blastomeres. Cleavage furrow of the fifth cleavage division } \\
\text { lies horizontally, blastomeres arranged in two layers }\end{array}$ \\
\hline 6 & $8 \pm 0.5$ & 64 blastomeres arranged in two or three layers \\
\hline 7 & $9 \pm 0.5$ & 128 blastomeres \\
\hline 8 & $12 \pm 1$ & Morula \\
\hline 9 & $14 \pm 1$ & Early blastula. Blastodisc edge is irregular \\
\hline $9+$ & $20 \pm 1$ & Late (high) blastula \\
\hline 10 & $23 \pm 2$ & Beginning of epiboly. Edge of blastoderm is sharp and clear \\
\hline 11 & $26 \pm 2$ & Blastoderm covers $1 / 3$ of the egg surface, its rim starts to thicken \\
\hline 12 & $29 \pm 3$ & Blastoderm covers $1 / 2$ of the egg surface \\
\hline 13 & $41 \pm 2$ & $\begin{array}{l}\text { Blastoderm covers } 4 / 5 \text { of the egg surface; embryonic shield and } \\
\text { axis formed }\end{array}$ \\
\hline 14 & $50 \pm 2$ & Blastoderm covers yolk entirely \\
\hline 15 & $53 \pm 5$ & $\begin{array}{l}\text { Beginning of mesoderm segmentation, formation of the first pair } \\
\text { of somites }\end{array}$ \\
\hline 16 & $57 \pm 5$ & $\begin{array}{l}4 \text { pairs of somites, formation of optic vesicles in advanced } \\
\text { embryos }\end{array}$ \\
\hline $16+$ & $60 \pm 5$ & $\begin{array}{l}6 \text { pairs of somites, formation of optic vesicles in late embryos. } \\
\text { Kuppfer's vesicle emerges }\end{array}$ \\
\hline
\end{tabular}


Table 1. Continued

\begin{tabular}{|c|c|c|}
\hline Stage & $\begin{array}{l}\text { Age } \tau_{n} / \tau_{0} \\
(\text { mean } \pm \mathrm{SD} \\
\quad n=12)\end{array}$ & Description \\
\hline 17 & $65 \pm 5$ & 10 pairs of somites \\
\hline 18 & $77 \pm 4$ & 18 pairs of somites. Olfactory vesicles in advanced embryos \\
\hline 19 & $80 \pm 3$ & $\begin{array}{l}20 \text { pairs of somites. Olfactory vesicles in most embryos, auditory } \\
\text { vesicles in advanced embryos. The size of Kuppfer's vesicle is } \\
\text { maximal }\end{array}$ \\
\hline 20 & $84 \pm 3$ & $\begin{array}{l}24 \text { pairs of somites. Auditory vesicles in most embryos, cavity in } \\
\text { olfactory vesicles and eye lens in advanced embryos }\end{array}$ \\
\hline 21 & $88 \pm 3$ & $\begin{array}{l}26 \text { pairs of somites. Most embryos have cavities in olfactory } \\
\text { vesicles and eye lens. Trunk-tail mound has raised up }\end{array}$ \\
\hline 22 & $94 \pm 3$ & $\begin{array}{l}30 \text { pairs of somites. Trunk-tail growth has begun, formation of } \\
\text { encephalomeres. Kuppfer's vesicle disappears }\end{array}$ \\
\hline 23 & $98 \pm 3$ & 33 pairs of somites. Formation of heart and otoliths \\
\hline 24 & $103 \pm 3$ & $\begin{array}{l}36 \text { pairs of somites. Irregular heart beats. Beginning of trunk-tail } \\
\text { mesoderm segmentation. Inner cells can be seen in notochord }\end{array}$ \\
\hline 25 & $108 \pm 4$ & 40 pairs of somites. Regular heart beats \\
\hline 26 & $116 \pm 4$ & 45 pairs of somites. Formation of anus \\
\hline 27 & $133 \pm 6$ & $\begin{array}{l}\text { Pigment in eye periphery of most embryos. Buds of pectoral fins. } \\
57 \text { pairs (incl. } 13 \text { postanal) of somites. Mean TL of embryos is } \\
3.5 \mathrm{~mm} \text {. Embryos may hatch occasionally }\end{array}$ \\
\hline $27+$ & $138 \pm 6$ & $\begin{array}{l}\text { Segmentation is complete. TL of embryos } 4.0-5.0 \mathrm{~mm} \text {. Pigment } \\
\text { in eye periphery also in late embryos }\end{array}$ \\
\hline 28 & $185 \pm 10$ & $\begin{array}{l}\text { Yellow pigment and guanine in eyes. The mouth-opening } \\
\text { emerges; beginning of hatching. Mean TL of embryos/prelarvae } \\
\text { is } 5.5 \mathrm{~mm}\end{array}$ \\
\hline 29 & $202 \pm 13$ & $\begin{array}{l}\text { Pigment in intestine; head is detached from yolk. Mass hatching } \\
\text { in our experiments. Mean TL of prelarvae at hatching is } 6.0 \mathrm{~mm}\end{array}$ \\
\hline 30 & $216 \pm 13$ & $\begin{array}{l}\text { Pectoral fins assume oblique position. Ear capsules enlarge, } \\
\text { semicircular canals and endolymphatic duct form. Hatching } \\
\text { continues. Mean TL of prelarvae is } 6.3 \mathrm{~mm}\end{array}$ \\
\hline
\end{tabular}

Synchronous cleavage divisions (stages 2-7) are followed through blastulation and epiboly. The relative linear rate of epiboly (Ignatieva, 1979) was 0.03$0.04 \mathrm{~mm} \tau_{0}{ }^{-1}$. The segmentation of trunk mesoderm was, as in other fishes, synchronous, with $1.48 \pm 0.03 \tau_{0}$ between the formation of successive pairs of somites. Somitogenesis was complete (59-60 pairs of somites) at stages 27-27+.

There was a high variation in the chronology of the development of embryos of the same progeny, as well as between progenies, especially at later stages. Hatching typically started at stage 28 ( $185 \tau_{0}$ from fertilization), and its timing was, as in other fishes, very variable. Hatching of externally normal (but at various stages of development) embryos was observed between 133 and $230 \tau_{0}$ (125 and 216 hours, respectively; stages 27-30 of development). Yolk was exhausted by $313-338 \tau_{0}(294-317 \mathrm{~h})$ after fertilization. 

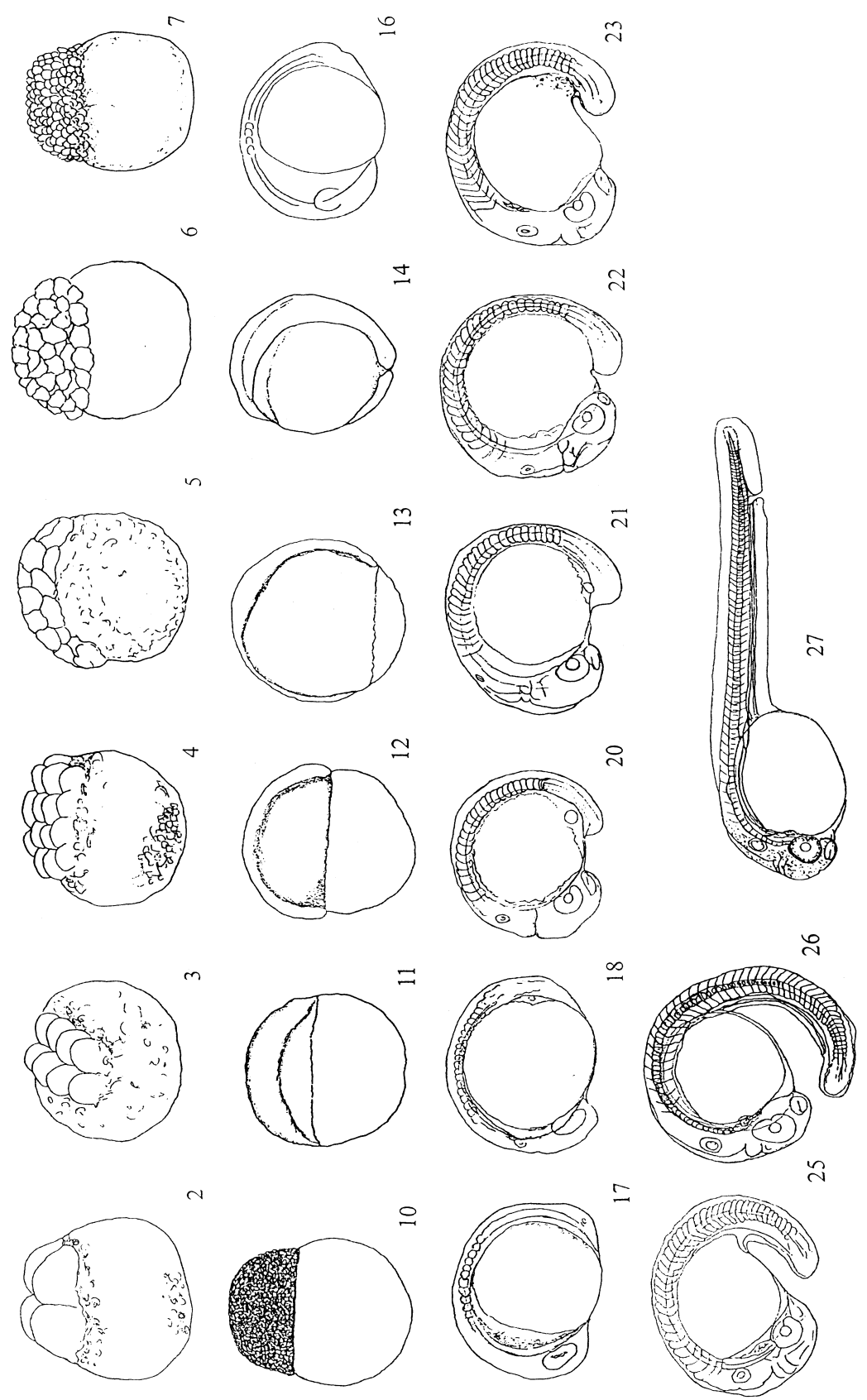

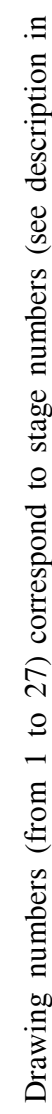

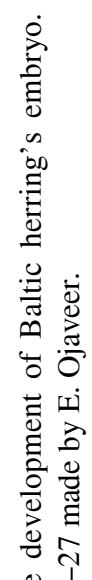

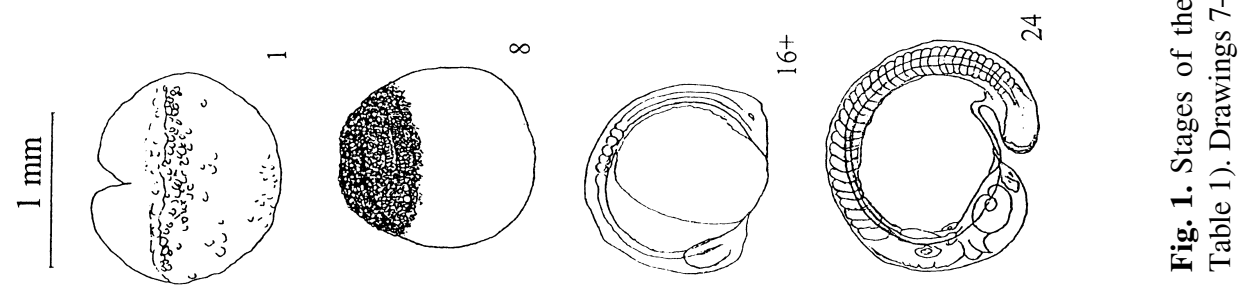




\section{DISCUSSION}

\section{Timing of Baltic herring development}

The morphological pattern of the development of Baltic herring has been investigated by Kryzhanovskij (1956), Rannak (1961), and Ojaveer (1988). Our results are in good accordance with these earlier studies.

The timing of development in Table 1 can be recalculated into astronomic time units (hours, minutes) at any temperature between approximately 5 and $12^{\circ} \mathrm{C}$, as the ratios of $\tau_{n} / \tau_{0}$ remain constant within the range of optimal temperatures for early development (Dettlaff \& Dettlaff, 1961; Dettlaff et al., 1987). The upper optimal temperature for Baltic herring embryos is $12-13^{\circ} \mathrm{C}$ (Saat \& Veersalu, 1996a), and severe abnormalities of embryos have been detected at $17^{\circ} \mathrm{C}$ (Ojaveer, 1981). The lower optimal temperature for Baltic herring embryos is approximately $5^{\circ} \mathrm{C}$. For example, stage 24 (heartbeats) could be detected at the age of $103 \tau_{0}$ at $10^{\circ} \mathrm{C}$ (this study) and $103 \tau_{0}$ at $7^{\circ} \mathrm{C}$ (calculated from Ojaveer, 1981). The corresponding values for 3 and $17^{\circ} \mathrm{C}$ were 126 and $70 \tau_{0}$, respectively (calculated from data in Ojaveer, 1981, 1988).

Variation in the rate of development among embryos of the same progeny is a rather common phenomenon in fish development, and the timing of stages in the tables of normal development is therefore given for the most advanced embryos (Dettlaff \& Vassetzky, 1991). Asynchrony in embryo development may result from both genetic and environmental factors. In the case of Pacific herring Clupea pallasi it has been shown that in unfavourable oxygen (Dushkina, 1988) and salinity conditions (Griffin et al., 1998) hatching is significantly delayed. In Baltic herring, the highest variation appeared in the hatching time. A wide variation in the hatching time (stage) of Baltic herring embryos was also observed by Kryzhanovskij (1956) and Ojaveer (1981).

Hatching in Baltic herring seems to be shifted to earlier stages as compared with another subspecies, Atlantic herring (Clupea harengus harengus L.). According to Johnston (1993), hatching of Atlantic herring embryos occurs $384 \mathrm{~h}$ after fertilization at $8^{\circ} \mathrm{C}$. As the $\tau_{0}$ dependence on temperature has been proved to be species specific (see Saat $\&$ Veersalu, 1996b for references), we used the $\tau_{0}$ values for Baltic herring (Saat \& Veersalu, 1996a) for recalculations, and got $354 \tau_{0}$, or over $100 \tau_{0}$ more than in Baltic herring. At the same time, the rate of somitogenesis in the two subspecies of $C$. harengus is rather similar, with mean intervals between the successive pairs of somites $1.48 \pm 0.03 \tau_{0}$ in Baltic herring, and $1.52(1.43-1.58) \tau_{0}$ in Atlantic herring $\left(5-12{ }^{\circ} \mathrm{C}\right.$; recalculated from data in Johnston et al., 1995). Differences in the hatching time (stage) may be caused, at least in part, by adaptations to different water salinity (see Vetemaa \& Saat, 1996 and Griffin et al., 1998 for references).

The two highly synchronous processes in fish embryo development, several first cleavage divisions (with an interval of $1 \tau_{0}$ ) and trunk mesoderm segmentation (Dettlaff et al., 1987), can be relatively easily followed in live embryos. The number of somite pairs served as one of the main morphological characters in the table of normal development of Baltic herring (Table 1), as well as in other fishes 
(Dettlaff \& Vassetzky, 1991). The time of the appearance of some other characters was quite variable and not fixed to a particular number of somites. For example, the formation of auditory and olfactory vesicles could be detected in embryos with a different number (18-25) of pairs of somites. At the same time, eye lenses and cavities in olfactory vesicles could usually be detected in embryos with 26 pairs of mesodermal somites. Kryzhanovskij (1956) found that these latter characters appeared simultaneously with the 24th pair of somites. However, his experiments were carried out at $14^{\circ} \mathrm{C}$, which is suboptimal for Baltic herring embryos (Saat \& Veersalu, 1996a).

\section{Comparison with other teleosts}

The timing of cleavage (until blastulation) is rather similar in different teleost species (Table 2). The period from insemination to the first cleavage in Baltic herring is longer than in species reproducing in fresh water (Saat \& Veersalu, 1996a). The timing of the further embryonic development of Baltic herring seems

Table 2. Timing of embryonic development in some teleost species $\left(\tau_{n} / \tau_{0}\right)$

\begin{tabular}{|c|c|c|c|c|c|c|}
\hline Stage, period & $\begin{array}{c}\text { Clupea } \\
\text { harengus } \\
\text { membras }\end{array}$ & $\begin{array}{l}\text { Oncorh- } \\
\text { ynchus } \\
\text { mykiss }\end{array}$ & $\begin{array}{l}\text { Salmo } \\
\text { salar }\end{array}$ & $\begin{array}{l}\text { Carassius } \\
\text { gibelio }\end{array}$ & $\begin{array}{l}\text { Cyprinus } \\
\text { carpio }\end{array}$ & $\begin{array}{l}\text { Misgurnus } \\
\text { fossilis }\end{array}$ \\
\hline 2 blastomeres & 3 & 2.5 & 2.15 & 2 & 2 & 2 \\
\hline 16 blastomeres & 6 & 5.5 & 5.15 & 5 & 5 & 5 \\
\hline Beginning of epiboly & 23 & 29 & 34 & 22 & 22 & 20 \\
\hline Epiboly $50 \%$ & 29 & 52 & 60 & 32 & 32 & 28 \\
\hline End of epiboly & 50 & 72 & 72 & 40 & 42 & 38 \\
\hline 1 pair of somites & 53 & 48 & 57 & 46 & 46 & 42 \\
\hline Optic vesicles & 57 & 56 & 66 & 50 & 50 & 46 \\
\hline 10 pairs of somites & 66 & 57 & 66 & 56 & 54 & 50 \\
\hline Auditory vesicle & 76 & 72 & 78 & 62 & 51 & 52 \\
\hline Heart beats & 103 & 96 & 99 & 84 & 80 & 80 \\
\hline Eye pigmentation & 133 & 112 & 120 & 86 & 86 & 92 \\
\hline Body pigmentation & 202 & 200 & 201 & 98 & 98 & $\sim 150$ \\
\hline Hatching & 202 & 272 & 283 & 176 & 170 & 102 \\
\hline Duration of epiboly & 27 & 43 & 38 & 18 & 20 & 18 \\
\hline $\begin{array}{l}\text { Beginning of epiboly - } \\
1 \text { pair of somites }\end{array}$ & 30 & 19 & 23 & 24 & 22 & 22 \\
\hline $\begin{array}{l}\text { Relative linear rate } \\
\text { of epiboly, } \mathrm{mm} / \tau_{0}\end{array}$ & 0.035 & $0.14 *$ & - & - & $0.07 *$ & $0.07 *$ \\
\hline $\begin{array}{l}\text { Mean diameter of } \\
\text { unfertilized egg, mm }\end{array}$ & 1.0 & 4.5 & 5.0 & 1.5 & 1.2 & 1.2 \\
\hline
\end{tabular}

Sources: O. mykiss, Ignatieva, 1991; S. salar, Gorodilov, 1983, 1990; M. fossilis, Kostomarova, 1991; C. gibelio, Savolainen, 1985; C. carpio, Soa, 1987; T. Saat, unpublished.

* Ignatieva, 1979. 
to be more similar to that of salmonids than cyprinids (Table 2). This reflects the phylogenetic closeness of clupeid and salmonid fishes. However, the timing of several stages of embryonic development in Baltic herring differs from that of salmonids. In some cases, these differences are probably due to the different size of eggs. In Atlantic salmon and rainbow trout the period of blastulation is longer, epiboly starts later and lasts longer than in species with smaller eggs; the mesoderm segmentation starts before half of the yolk is overgrown (Table 2). The relative linear rate of epiboly in freshwater fishes is correlated with the egg size (Table 2). However, the rate of epiboly in Baltic herring is very low as compared with freshwater species (Table 2).

Another process that proceeds slower in Baltic herring than in freshwater (or anadromous) species is mesoderm segmentation. Intervals between the appearance of successive pairs of somites in Baltic and Atlantic herring are approximately $1.5 \tau_{0}$, but in carp, loach, Atlantic salmon, and rainbow trout they almost equal $1.0 \tau_{0}$, and in chum salmon $1.1 \tau_{0}$ (Ignatieva, 1979; Gorodilov, 1990).

\section{ACKNOWLEDGEMENTS}

We thank Prof. E. Ojaveer for providing the original illustrations of Baltic herring development, and the staff of the Pärnu field station, the Estonian Marine Institute, for technical aid and support. This study was partly supported by the Estonian Science Foundation (grants Nos. 893 and 2473) and the project "Biodiversity of the Estonian fauna".

\section{REFERENCES}

Balon, E. K. 1981. About processes which cause the evolution of guilds and species. Environ. Biol. Fishes, 6, 129-138.

Balon, E. K. 1983. Epigenetic mechanisms: reflections on evolutionary processes. Can. J. Fish. Aquat. Sci., 40, 2045-2058.

Dettlaff, T. A. \& Dettlaff, A. A. 1961. On relative dimensionless characteristics on development duration in embryology. Arch. Biol., 72, 1-16.

Dettlaff, T. A. \& Vassetzky, S. G. (eds.) 1991. Animal Species for Developmental Studies. Vol. 2. Vertebrates. Consultants Bureau, New York and London.

Dettlaff, T. A., Ignatieva, G. M. \& Vassetzky, S. G. 1987. The problem of time in developmental biology: Its study by the use of relative characteristics of development duration. In Soviet Scientific Reviews, Section F. Physiology and General Biology. Reviews. Vol. 1, Part A (Turpaev, T. M. \& Yablokov, A. V., eds.), pp. 1-88. Harwood Academic Publishers GmbH, Chur-London-Paris-New York-Melbourne.

Dushkina, L. A. 1988. Biology of Marine Herrings During Early Ontogenesis. Nauka, Moscow (in Russian).

Emelianov, S. V. (ed.) 1968. The Tempo of Individual Development of Animals and Its Changes During Evolution. Nauka, Moscow (in Russian).

Fuiman, L. A. 1985. Contributions of developmental characters to a phylogeny of catostomid fishes, with comments on heterochrony. Copeia, No. 4, 833-846. 
Gorodilov, Y. N. 1983. Stages of embryonic development in Atlantic salmon Salmo salar L. Part 2. Sb. nauchn. tr. GosNIORH, 200, 107-126 (in Russian).

Gorodilov, Y. N. 1990. A significance of temporal factor in the regulation of the embryonic development (lower vertebrates as an example). Ontogenez, 21, 319-330 (in Russian).

Griffin, F. J., Pillai, M. C., Vines, C. A., Kääriä, J., Hibbard-Robins, T., Yanagimachi, R. \& Cherr, G. N. 1998. Effects of salinity on sperm motility, fertilization, and development in the Pacific herring, Clupea pallasi. Biol. Bull., 194, 25-35.

Ignatieva, G. M. 1979. Early Embryogenesis of Fishes and Amphibians. Nauka, Moscow (in Russian).

Ignatieva, G. M. 1991. The rainbow trout Salmo gairdneri. In Animal Species for Developmental Studies. Vol. 2. Vertebrates (Dettlaff, T. A. \& Vassetzky, S. G., eds.), pp. 89-124. Consultants Bureau, New York and London.

Johnston, I. A. 1993. Temperature influences muscle differentiation and the relative timing of organogenesis in herring (Clupea harengus) larvae. Mar. Biol. (New York), 116, 363-379.

Johnston, I. A., Vieira, V. L. A. \& Abercromby, M. 1995. Temperature and myogenesis in embryos of the Atlantic herring Clupea harengus. J. Exp. Biol., 198, 1389-1403.

Kostomarova, A. A. 1991. The loach Misgurnus fossilis. In Animal Species for Developmental Studies. Vol. 2. Vertebrates (Dettlaff, T. A. \& Vassetzky, S. G., eds.), pp. 125-144. Consultants Bureau, New York and London.

Kryzhanovskij, S. G. 1956. Materials on the development of clupeid fishes. $\operatorname{Tr}$. IMZ, 17, 1-253 (in Russian).

Ojaveer, E. 1981. Influence of temperature, salinity and reproductive mixing of Baltic herring groups on its embryonal development. Rapp. P.-V. Rèun. Cons. Int. Explor. Mer, 178, 409-415.

Ojaveer, E. 1988. Baltic Herrings. Biology and Management. Agropromizdat, Moscow (in Russian).

Paine, M. D. \& Balon, E. K. 1984. Early development of rainbow darter, Etheostoma caeruleum, according to the theory of saltatory ontogeny. Environ. Biol. Fishes, 11, 277-299.

Rannak, L. 1961. Räime selgroo ontogeneesist seoses teiste elundite arengu ja metamorfoosiga. In Hüdrobioloogilised Uurimused, Vol. 2, pp. 375-411. ZBI, Tartu.

Saat, T. \& Veersalu, A. 1996a. Duration of synchronous cleavage cycles and rate of development at different temperatures in the Baltic herring. J. Fish Biol., 48, 658-663.

Saat, T. \& Veersalu, A. 1996b. The rate of early development in perch Perca fluviatilis L. and ruffe Gymnocephalus cernuus (L.) at different temperatures. Ann. Zool. Fenn., 33, 693-698.

Savolainen, M. 1985. Stages of embryonic development in bisexual and unisexual forms of Carassius auratus gibelio. Acta commentat. univ. Tartu., 718, 51-61 (in Russian).

Soa, I. 1987. Embryonic development of the carp. MSc dissertation, University of Tartu.

Vetemaa, M. \& Saat, T. 1996. Effects of salinity on the development of fresh-water and brackishwater ruffe Gymnocephalus cernuus (L.) embryos. Ann. Zool. Fenn., 33, 687-691.

\section{Räime (Clupea harengus membras) lootelise arengu kronoloogia}

\section{Aune Veersalu ja Toomas Saat}

Pärnu lahe koelmutelt püütud räimede munarakud seemendati ja inkubeeriti püsival temperatuuril. Räime loote arengus viljastamisest kuni koorumiseni eristati 30 arengustaadiumit. Loodete vanus erinevatel arengustaadiumitel väljendati suhtelistes ajaühikutes $\left(\tau_{0}\right)$. Räime loodete arengu ajaline käik oli sarnane lõhilaste omale, ent erines karpkalaliste omast. 